УДК 94(437.1):94(437.6):[(438)+(437.1)+(439)+(437.6)]

DOI 10.24919/2519-058x.5.116965

Віталій АНДРЕЙКО,
orcid.org/0000-0001-9797-831X

кандидат історичних наук, дочент кафедри міжнародних студій та суспільних комунікацій ДВНЗ «Ужсгородський національний університет»

(Украӥна, Ужгород) andreykovitaliy@gmail.com

\title{
ЧЕСЬКА І СЛОВАЦЬКА РЕСПУБЛІКИ В СИСТЕМІ ВІДНОСИН КРАЇН ВИШЕГРАДСЬКОЇ ЧЕТВІРКИ «V4»
}

\begin{abstract}
У статті автор розглядає історичні аспекти створення та основні моменти діяльності «Вишеграду», регіонального співробітництва краӥн Центральної та Східної Свропи, зокрема сучасні питання і проблеми взаємодії Чеської і Словацької Республік у рамках регіональної співпраці, транскордонного співробітництвва, спільних зовнішньополітичних інтересів та взаємовигідної зовнішньоекономічної політики, яка була спрямована на відродження відкритої ринкової економіки, інтеграцію до ЄС і НАТО.
\end{abstract}

Ключові слова: Чеська Республіка, Словацька Республіка, Вишеградська четвірка, європейська і євроатлантична інтеграчія, регіональне співробітництво, ЄС, НАТО.

Jim. 33.

Vitaliy ANDREIKO,

Ph D (History), Associate Professor, Associate Professor of International Studies and Public Communications Department, SHEE Uzhhorod State University

(Ukraine,Uzhhorod)andreykovitaliy@gmail.com

\section{CZECH AND SLOVAK REPUBLICS WITHIN THE FRAMEWORK OF RELATIONSHIPS OF THE COUNTRIES OF VISEGRAD FOUR}

In the article the author studies the historical aspects of the formation of "Visegrad» and the main points of its activity, cooperation of Central and Eastern European countries, in particular, the contemporary issues and problems of the interaction between Czech Republic and Slovak Republic within the framework of regional and cross-border cooperation, common foreign policy interests and mutually beneficial foreign economic policy aimed at reviving an open market economy and accession to the EU and the NATO.

The article also shows that the system of interstate cooperation between Czech Republic and Slovakia has proved its effectiveness and stability for many years, and the countries' common interests in the post-integration period after acceding to the North Atlantic Alliance and the European Community have had significant historical traditions. These remarkable events in the life of the young states were preceded by radical reforms in the political, economic and legal spheres. At the same time, the complicated tasks of state building, consolidation of the political community and the whole society around the idea of the country's return to Europe were solved.

The author holds that, despite the activity of the Visegrad countries towards integration, both in the centraland common European directions, each of these states follows its own course while pursuing its national interests. Sometimes, a rivalry between them can be felt, which was too obvious in the first stages of the process of their accession into European and Euro-Atlantic structures.

It should be noted that, in the context of implementing the primary - European - choice of Ukraine, the study of Czech Republic's and Slovakia's experience in the priority of their foreign relations is topical and extremely significant from the scientific-theoretical and practical points of view.

At the present stage of development, the Czech-Slovak regional collaboration within the framework of Visegrad Four in the context of inter-governmental cooperation has turned into an important integral part of the new interaction architecture in Central Europe and the European continent on the whole. Czech Republic and Slovakia implement their foreign and security policy, common with that of the EU, on the international scene. It agreeably integrates into the EU common internal market, trade and customs. That is, the coordinated Czech-Slovak intergovernmental cooperation in realization of their integration interests and tasks comes to the forefront.

Key words: Czech Republic, Slovak Republic, Visegrad Four, European and Euro-Atlantic integration, regional cooperation, EU, NATO.

Ref. 33. 
Виталий АНДРЕЙКО,

кандидат исторических наук, доцент, доиент кафедры международных студий и общественных коммуникаций ГВУЗ «Ужсгородский национальный университет»

(Украина, Ужгород) andreykovitaliy@gmail.com

\section{ЧЕШСКАЯ И СЛОВАЦКАЯ РЕСПУБЛИКИ В СИСТЕМЕ ОТНОШЕНИЙ СТРАН ВЫШЕГРАДСКОЙ ЧЕТВЕРКИ «V4»}

В статье автор рассматривает исторические аспекты создания и основные моменты деятельности «Вишеграда», регионального сотрудничества стран Центральной и Восточной Европь, в частности современные вопросы и проблемы взаимодействия Чешской и Словацкой Республик в рамках регионального и трансграничного сотрудничества, общих внешнеполитических интересов и взаимовыгодной внешнеэкономической политики, направлений на возрождение открытой рыночной экономики, интеграцию в ЕС и HATO.

Ключевые слова: Чешская Республика, Словацкая Республика, Вышеградская четвёрка, европейская и евроатлантическая интеграция, региональное сотрудничество, ЕС, НАТО.

Лит. 33.

Постановка проблеми. Система міждержавного співробітництва Чеської Республіки та Словаччини протягом багатьох років засвідчила свою ефективність і стабільність, а спільні інтереси країн в постінтеграційний період після вступу у Північноатлантичний альянс і Європейське Співтовариство, мають значні історичні традиції. Цим визначним подіям у житті молодих держав передували кардинальні реформи в політичній, економічній та правовій сферах. Паралельно розв'язувалися непрості завдання державного будівництва, консолідації політикуму та всього суспільства навколо ідеї повернення країни у Європу.

Незважаючи на активність країн Вишеграду у напрямі інтеграції як центрально-, так і загальноєвропейської, кожна із цих держав дотримується власного курсу при проведенні своїх національних інтересів. Іноді можна відчувати навіть суперництво між ними, що відбилося на перших же етапах їхнього інтеграційного процесу в європейські та євроатлантичні структури.

Варто відзначити, що у контексті реалізації головного - європейського - вибору України вивчення досвіду пріоритетних зовнішніх зв язків Чехії і Словаччини актуальне і винятково важливе 3 науково-теоретичного і практичного погляду.

На сучасному етапі розвитку, чесько-словацька регіональна співпраця в рамках Вишеградської четвірки в контексті міждержавного співробітництва, перетворилася на вагомий невід’ємний складовий елемент нової архітектури співробітництва в регіоні Центральної Європи і європейського континенту загалом. На міжнародній арені Чехія і Словаччина реалізують спільну зовнішню і безпекову політику СС. Вона погоджено інтегрується до спільного внутрішнього ринку, торговельного і митного союзу СС. Тобто, на перший план виступає злагоджена чесько-словацька міждержавна співпраця в реалізації інтеграційних інтересів та завдань.

Аналіз досліджень. Українська історична наука зробила вагомі кроки у вивченні системи новітніх міждержавних відносин Чехії і Словаччини, як і інших зарубіжних держав Центральної та Східної Свропи. Окремі аспекти досліджуваної теми висвітлено в публікаціях українських істориків В. Андрейка [1; 2; 3], С. Віднянського [5; 6; 7], I. Вовканича [8; 9; 10], Т. Герасимчук [12], Д. Мороза [21; 22], С. Мотрук [23], Р. Постоловського [24], А. Стативки [26] та інших з новітньої історії, системної постсоціалістичної трансформації, зовнішньої політики, європейської і трансатлантичної інтеграції ЧР і СР.

Мета статті. Розкрити особливості процесу формування міждержавних відносин ЧР і СР, визначити роль чесько-словацького співробітництва в контексті діяльності Вишеградської четвірки.

Виклад основного матеріалу. Питання становлення і розвитку системи міждержавних відносин між Чеською Республікою і Словацькою Республікою після проголошення ними незалежності з 1 січня 1993 р. має значну специфіку, порівняно з іншими центральноєвропейськими країнами та пострадянськими державами. По-перше, чеський і словацький народи та його політичні еліти 
на початку 1990-х рр. продемонстрували на тлі колишніх соціалістичних федерацій (Югославіі) можливість цивілізованого, мирного і еволюційного саморозпуску чесько-словацької федерації. По-друге, припинення чесько-словацького федеративного союзу і проголошення незалежності ЧР та СР відбулося на основі і в рамках чинних конституційних норм та законів. I, по-третє, чеською і словацькою стороною ще у федерації заздалегідь готувалися умови для повнокровного функціонування національної державності з перших днів незалежності ЧР та СР і договірно-правова основа їх подальшого тісного міждержавного співробітництва.

Значного імпульсу з перших днів незалежності отримала участь ЧР і СР в процесах міжнародної регіональної інтеграції на принципах центральноєвропейської ідентичності $[30 ; 31 ; 32]$. 15 лютого 1991 р. в угорському місті Вишеград чехословацьким президентом Вацлавом Гавелом, польським - Лехом Валенсою та угорським прем'єр-міністром Йожефом Анталом була підписана «Декларація про співробітництво Чеської і Словацької Федеративної Республіки, Республіки Польща і Угорської Республіки на шляху європейської інтеграції». У Декларації були зафіксовані такі спільні завдання: повне відновлення державного суверенітету, демократії і свободи; ліквідація всіх суспільних, економічних і культурно-духовних залишків тоталітарної системи; розбудова парламентської демократії, сучасної правової держави, дотримання прав людини і основних свобод; створення розвиненої ринкової економіки; інтеграція до європейської політичної, економічної, безпекової і правової системи [29].

У Вишеградській декларації також було відзначено, що держави вважають передумовою розбудови демократії і громадянського суспільства центральноєвропейську ідентичність і поглиблення співробітництва між країнами-учасницями з метою їх загальноєвропейської інтеграції.

Держави, що підписали документ, визначили низку конкретних завдань, які необхідно було здійснити, щоб досягти євроінтеграційної мети:

1) встановлення гармонійного співробітництва та тісних зв'язків з європейськими інституціями, проведення консультацій з питань безпеки;

2) створення безконфліктних зв'язків між державами, установами, конфесіями та громадськими об'єднаннями;

3) сприяння розвитку економічного співробітництва та взаємовигідної торгівлі;

4) розвиток інфраструктури, комунікацій та активізація екологічного співробітництва;

5) розвиток співпраці територіальних спільнот тощо [29].

Вишеградською декларацією 1991 р.не передбачалося створення якихось спеціальних організаційних структур для керівництва діяльністю цього міжнародного регіонального об'єднання. Вишеград, по суті, - це добровільна політична асоціація центральноєвропейських постсоціалістичних держав. Він виступав тільки як координаційний орган, що сприятиме входженню країн-членів об'єднання в європейське співтовариство, в його політичні та економічні інституції. Втім уже в першій половині 1990-х рр. у його рамках склалася багаторівнева система співробітництва і постійних взаємозв'язків - від президентських до урядових і міністерських структур. Механізми вишеградської співпраці давали змогу від самого початку досить ефективно координувати кроки країн-учасниць Вишеградської групи на шляху до ЄС і НАТО.

Після проголошення незалежності Чехія і Словаччина фактично мали рівні стартові позиції на шляху інтеграції до СС і НАТО [25, 1]. 31993 р. ЧР і СР передусім одночасно розпочали рух до вступу в Північноатлантичний альянс. Це відбувалося у загальному руслі інтеграції центральноєвропейських постсоціалістичних держав до євроатлантичних структур. Якщо в 1989 - 1992 pр. більшість центральноєвропейських країн проявляли обережність в оцінці можливих варіантів формування нової системи європейської безпеки, то з 1993 - 1994 рр. під дією низки об'єктивних процесів набір варіантів почав звужуватися, і до 1997 р. етап дискусій закінчився. Стало зрозумілим, що відбулася зміна поглядів - єдина Європа формується не на основі зближення Сходу i Заходу, а в результаті поступового розширення західних організацій. Це відобразилося у нових доктринах та документах Європейського Союзу і НАТО [19, 45].

Водночас участь ЧР і СР в багатосторонньому центральноєвропейському співробітництві в рамках Вишеградської групи протягом першої половини 1990-х рр. не набрала достатнього розмаху. Радше, навпаки, Чехія і Словаччина з різних причин на середину 1990-х рр. перетворилися 
нагальмівний чинник розвитку взаємодії «вишеградської четвірки» [27]. По-перше, чеське державне керівництво із зовнішніх причин, а словацьке - із внутрішньополітичних притримувалися дещо упереджених поглядів щодо основних завдань і напрямів співпраці країн-членів Вишеграду. Прем’єр-міністр ЧР Вацлав Клаус уже з 1992 р. вважав другорядною політичну інтеграцію центральноєвропейських постсоціалістичних країн у рамках Вишеградської групи. Він вбачав першочерговою необхідність економічної інтеграції держав регіону. Словацький прем'єр Владімір Мечіар та очолюваний ним Рух за демократичну Словаччину з кінця 1994 р. взагалі почали сповідувати ідею специфічного, т. зв. «третього шляху» розвитку СР, зокрема і на міжнародній арені. Проголошувалися гасла щодо виняткового геополітичного розташування Словаччини як «мосту» між Сходом і Заходом, утверджувалася ідея «нейтралітету» СР [20]. Тому увага ЧР і СР до розвитку вишеградської співпраці на середину 1990-х рр. суттєво знизилася.

По-друге, сама двостороння чесько-словацька міждержавна взаємодія у першій половині 1990-х рр. не змогла стати своєрідним «двигуном» Вишеграду та центральноєвропейської інеграції. Мусимо навіть констатувати, що після «оксамитового розлучення» та проголошення незалежності ЧР і СР зовнішньополітичні взаємини між двома новими європейськими демократіями на декілька років потрапили в смугу стагнації [14].

Як засвідчує аналіз, основною причиною гальмування поступального розвитку двосторонніх стосунків були системні відмінності внутрішньополітичного розвитку Чехії і Словаччини. У період 1993 - 1998 рр. при владі в кожній із цих країн перебували ідейно відмінні чи й протилежні за характером політичні сили [13].

Що стосується Чехії, то внутрішньополітична стабільність у державі та ідейна визначеність правлячих чеських сил, незмінний прозахідний курс на міжнародній арені забезпечували послідовність зовнішньополітичної лінії ЧР щодо СР. Втім, у стосунках зі Словаччиною, на наш погляд, чеські правлячі кола свідомо чи несвідомо в 1993 - 1998 рр. все ж допустилися низки помилок [11].

По-перше, за інерцією продовжувалася неправильна лінія чеських правоцентристських політичних сил останнього етапу існування федерації, яку умовно можна назвати «позбутися тягаря Словаччини». Так само, як впродовж 1990 - 1992 рр. деякі політичні лідери чеських партій, особливо В. Клаус, готові були пожертвувати єдиною державою зі словаками для того, щоб соціально-економічна відсталість Словаччини не гальмувала здійснення ринкових реформ у Чехії i, не останнім чином, довести на чеському експерименті чистоту і «єдину» правильність «клаусотерапії», з 1993 р. чеська влада, і не безпідставно, вважала, що без співробітництва 3 СР вона набагато швидше забезпечить самостійну інтеграцію країни до СС і НАТО. По-друге, на дистанціювання Словаччини від ЧР, чеська сторона дещо спрощено відповіла демонстративним ігноруванням недемократичного мечіарівського режиму. Прага в 1990-ті рр. нерідко надавала притулок своєрідним новим словацьким «дисидентам» - особам, яких $з$ політичних мотивів переслідували у Словаччині. Це викликало відверте роздратування в Братиславі і різноманітні спроби дискредитувати ЧР на міжнародній арені. По-третє, через одіозність В. Мечіара майже припинилися чесько-словацькі контакти на вищому державному рівні. Відповідно, почали гальмувати й інші елементи системи і механізму чесько-словацького міждержавного співробітництва [28].

Водночас, як цілком справедливо погоджено вказують чеські, словацькі та інші вчені, міждержавне співробітництво ЧР і СР в 1993 - 1998 рр. все ж успішно функціонувало у сферах, не обтяжених політико-ідейними проблемами, насамперед в економіці. Тут певний час ефективно працювали механізми валютно-грошового союзу та поступового переходу двох незалежних держав до національної грошової одиниці [17].

Успішно діяв чесько-словацький митний союз, який не дозволив згорнути торгові, виробничо-коопераційні та інші зв'язки після розпаду федерації, що могло б призвести до колапсу національних економік, передусім словацької. Двосторонні валютний і митний союзи мали організаційно інституйовані керівні структури на чолі зі змішаними радами. Інтенсивно створювалися змішані міжурядові та міжвідомчі (міжміністерські) комісії за основними напрямами співробітництва, в т. ч. в економічній, гуманітарній та культурній сферах. Чеська сторона постійно пропо- 
нувала посилення координації кроків двох держав на міжнародній арені, особливо - поглиблення взаємодії міністерств закордонних справ ЧР і СР у справі європейської та євроатлантичної інтеграції [16].

У 1999 р. Словаччина була включена до складу 11 країн-кандидатів на повноцінне членство в ЄС. 15 лютого 2000 р. у Брюсселі відбулася офіційна церемонія початку переговорного процесу про вступ Словаччини в Свропейський Союз. При цьому лідери країни виходять із того, що одержання повноправного членства в СС неможливе без «парасольки» НАТО. Зі свогобоку, керівництво цього блоку вважало обов'язковою модернізацію й реструктуризацію словацької армії, що вимагало значних фінансових коштів.

1 червня 2001 р. на зустрічі в Кракові прем’єр-міністрів країн Вишеградської групи було підкреслено, що інші члени Вишеградської групи - Польща, Угорщина та Чехія, будуть виступати за прийом Словаччини до НАТО. Прем'єр-міністр Словаччини М. Дзурінда відзначив, що створення «вишеградської армії» буде сприяти ефективності цього блоку [4].

На початку нового тисячоліття, із досягненням практично всіх основних завдань Вишеградської групи, розгорнулася дискусія про доцільність продовження співробітництва держав у рамках «Вишеграду». У червні 2002 р. в угорському місті Остжихом відбулася важлива зустріч, на якій, між іншим, було збільшено суму членських внесків V4 до Міжнародного Вишеградського Фонду [33], а також прийнято документ про визначення ролі головування у Вишеградській групі. Новий шлях співробітництва держав V4 мала намітити серія чергових конференцій, метою яких також було створення простору для пожвавлення ідеї співпраці країн V4 [17, 48].

Перша конференція відбулася 31 жовтня 2002 р., а її назва говорить сама за себе: «Вишеградська група і Європейський Союз». Обговорювали передусім обмін досвідом щодо комунікаційних стратегій, пов'язаних зі вступом до ЄC, шляхи подальшого співробітництва держав V4 після входження до Унії, а також можливості просування спільних інтересів у межах Євросоюзу. Того самого року 6-7 грудня зібрався неформальний з'їзд керівників урядів держав V4. До головних тем розмови належала можливість співробітництва V4 у сфері політики безпеки, промоція Вишеградської групи серед інших європейських країн [18].

Прем'єр-міністри держав V4 висловилися за продовження співробітництва в рамках Вишеградської групи і погодилися, що у зв'язку зі вступом до ЄС настав час розробити стратегію подальшого функціонування V4.

Друга конференція була скликана 6 лютого 2003 р. і мала назву «Охорона спільного простору держав Вишеградської групи». Обговорювалося активне співробітництво, яке б гарантувало безпеку в регіоні й одночасне дотримання угод Шенгену, обмеження впливу організованої злочинності та тероризму, боротьбу з нелегальною імміграцією і торгівлею, а також дистрибуцією наркотиків [15, 34-47].

Третя конференція, організована 29 квітня 2003 р., стосувалася освітніх систем країн V4. Її метою було насамперед порівняння досвіду і обмін поглядами на стан, реформу, фінансування й майбутнє освітніх систем окремих держав V4 та налагодження можливого співробітництва. Після тієї серії конференцій мали місце чергові зустрічі різного характеру. Приміром, на початку листопада 2003 р. президенти V4 зустрілися в Будапешті й знову підтвердили висновок, що співробітництво держав має тривати і після вступу до $\mathrm{CC}$, однак воно повинно набути іншого характеру, такого, наприклад, як СЕFТА [16].

У березні 2004 р., напередодні вступу країн V4 до СС, голови урядів зустрілися у Чехії, щоб визначити роль Вишеградської групи в межах Євросоюзу, насамперед у контексті Європейської Конституції. На тому ж тижні в Кошице зустрілися глави держав V4 [16].

Перша зустріч V4 після набуття членства в СС мала місце 12 травня 2004 р.в Кромежижу. Прем'єр-міністри знову вирішили, що співробітництво між державами V4 триватиме й надалі. Вишеградська група буде насамперед орієнтуватися на співробітництво СС із державами Східної Європи, надаючи підтримку для України, Білорусі, Болгарії, Румунії й Хорватії. Очільники урядів висловили переконання, що із входженням держав V4 до структур Унії, взаємне співробітництво щодо конкретних проектів поліпшиться. Відмовилися також від розширення V4 за рахунок інших країн, таких як Австрія або Словенія. 
У жовтні 2004 р. співпраця V4 набула нового виміру: Краків прийняв перший Форум Регіонів країн Вишеградської четвірки, які підписали декларацію про кооперацію з партнерами з Польщі, Чеської Республіки, Угорщини і Словаччини [14].Щороку у Вишеградській групі за чергою головує одна з країн-учасників. У контексті дослідження зовнішніх зв 'язків Чеської Республіки і Словаччини з країнами-партнерами Вишеградської групи, перспективи розвитку та загальні інтереси міжнародних акторів відіграють неабияку роль у висвітленні міждержавних відносин у період підготовки до вступу в СС і НАТО та в постінтеграційний період. Процес удосконалення діяльності країн Вишеградської четвірки та їх взаємних двосторонніх та багатосторонніх стосунків у багатьох галузях співробітництва триває. Водночас практична перевірка механізмів координації і партнерства довела свою ефективність.

Висновки. До вступу у Північноатлантичний альянс та Європейський союз Словаччина (на відміну від інших країн Вишеграду)перебувала у ставленні до інтеграційного процесу в стані спокою: не проводилися реформи, які потрібні були для досягнення стабільності демократичних інститутів, для створення правової держави, дотримання прав людини і захисту національних меншин. Більше того, відносини з СС та НАТО у вказаний період характеризувалися недовірою, багаторазовими демаршами і взаємними звинуваченнями.

Сьогодні ЧР та СР є членами Вишеградської групи. Країни Вишеградського блоку в стратегічному сенсі були об'єднані спільними потребами, інтересами та метою. Вони насамперед були зацікавлені у проведенні активної зовнішньої політики, спрямованої на забезпечення умов для трансформації внутрішнього становища та зміцнення свого міжнародного середовища.Процес удосконалення діяльності країн Вишеградської четвірки та їх взаємних двосторонніх та багатосторонніх стосунків у багатьох галузях співробітництва триває. Водночас практична перевірка механізмів координації та партнерства довела свою ефективність.

Сучасний постінтеграційний етап співробітництва ЧР та СР в системі країн «Вишеграду» після розширення Євросоюзу і Північноатлантичного Союзу характеризується розгортанням міждержавного співробітництва на якісно нових засадах і принципах. На міжнародній арені Чехія і Словаччина реалізують спільну зовнішню і безпекову політику СС і НАТО. Вона погоджено інтегруюється до спільного внутрішнього ринку, торговельного і митного союзу ЄС.

Що стосується України, то стратегічно виправданим був і залишається пріоритет поглиблення співробітництва з державами Вишеградської групи у напрямі наближення нашої країни до об'єднаної Свропи. Зі свого боку, країни Вишеграду є зацікавленими у формуванні зони безпеки i стабільності на своїх кордонах, розширення демократичного простору на Схід, а тому стали ініціаторами й активними прихильниками «Східного партнерства» і прибічниками підписання Угоди про асоціацію між Україною та ЄС. Важливим є факт того, що наші західні сусіди готові ділитися досвідом євроінтеграції, політичної модернізації, динамічних політичних та соціально-економічних реформ.

\section{СПИСОК ВИКОРИСТАНИХ ДЖЕРЕЛ І ЛІТЕРАТУРИ}

1. Андрейко В. І. Досвід чесько-словацького співробітництва в контексті інтеграційної стратегії України / В. І. Андрейко // Studia Slovakistica.Українсько-Словацькі діалоги. Літературознавство: Історія. - Ужгород: УжНУ, 2005. - С. 158-167.

2. Андрейко В. Система зовнішньоекономічного співробітництва ЧР і СР в період 1990-х - початку 2000-х років / В. Андрейко // Науковий вісник Ужгородського університету. Серія: Історія. - Ужгород: Видавництво УжНУ «Говерла», 2006. - Випуск 16. - С. 99-106.

3. Андрейко В. Системний підхід до вивчення еволюції новітніх міждержавних стосунків Чехії і Словаччини / В. Андрейко // Науковий вісник Ужгородського університету. Серія: Історія. - Ужгород: Вісник Карпат, 2005. - Випуск 14. - С. 101-109.

4. Бокало Н. Проблеми і перспективи демократизації в країнах Центрально-Східної Свропи (на прикладі Вишеградської четвірки) / Н. Бокало, С. Трохимчук. - Львів, 2000. - 68 с.

5. Віднянський С. Взаємодія у часників Вишеградської групи із зовнішньополітичним середовищем 3 етнополітичних питань / С. Віднянський // Міжнародні зв'язки України: наукові пошуки і знахідки. - 2013.Вип. 22. - С. 253-264. 
6. Віднянський С. Зовнішня політика України: еволюція концептуальних засад та проблеми реалізації / С. Віднянський // Український історичний журнал. - 2011. - № 4. - С. 55-76.

7. Віднянський С. Українсько-словацькі відносини: здобутки і перспективи / С. Віднянський // Науковий вісник Дипломатичної академії України. - 2002. - Вип. 7. - С. 221-229.

8. Вовканич І. Постсоціалістична трансформація в Чеській Республіці: специфіка і етапи / I. Вовканич // Carpatica - Карпатика. - Ужгород: УжНУ, 2003. - Вип.21. Політологічні студії: історія, теорія і практика.- С. 198-210.

9. Вовканич I. Становлення міждержавних взаємин Чехії, Словаччини та України / I. Вовканич // Міжнародні зв'язки України: наукові пошуки і знахідки. - 1998. - Вип. 7. - С. 225-229.

10. Вовканич I. Методологія порівняльного аналізу перехідних періодів історії країн Центрально-Східної Європи другої половини XX ст. / І. Вовканич // Carpatica Карпатика. - Ужгород: Два кольори, 2001. - Вип. 10. Актуальні проблеми політичного та культурного розвитку Карпатського регіону в XIX ХХ століттях. - С. 161-169.

11. Вышеградская Европа: откуда и куда? Два десятилетия по пути реформ в Венгрии, Польше, Словакии, Чехии / под ред. Шишелиной Л. Н. - Москва: Весь мир, 2010. - 568 с.

12. Герасимчук Т. Країни Центральної Європи в політиці Європейського Союзу (1989 - 2004 рр.) / Т. Герасимчук. - К., 2005. - С. 14-21.

13. Гойло І. Інтеграційні процеси в Центральній Європі: проблеми і труднощі. Європа: ідеї та процеси / І. Гойло // Матеріали наукового симпозіуму. - Чернівці, 1998. - 192 с.

14. Досвід країн Вишеградської четвірки на шляху до $\mathrm{CC}$ : Можливості для України: Аналітичні оцінки. - Ужгород, 2003. - 136 с.

15. Дулеба А. Словацько-українські відносини після 1991 року / А. Дулеба // Досвід країн Вишеградської четвірки на шляху до ЄС: можливості для України: аналітичні оцінки / Нац. ін-т стратег. дослідж. (Закарпат. філ.), Фонд ім. Ф. Еберта; за ред. кол.: В. І. Андрійко, О. С. Власюк, С. І. Мітряєва (голов. ред.). Ужгород: Видавництво В. Падяка, 2003. - С. 34-47.

16. Євроінтеграція: досвід країн Вишеградської четвірки та українські реалії/ Інститут економічних досліджень та політичних консультацій, Угорський інститут міжнародних справ (Угорщина), Інститут центральноєвропейської політики CEPI (Словаччина), Інститут економічної політики EUROPEUM (Чехія); за ред. Коссе I. - К.: Інститут економічних досліджень та політичних консультацій, 2014. - 88 с.

17. ЄС та місцеве самоврядування: досвід вишеградських міст та українська перспектива: Науковометодичний посібник / За загальною ред. Соскіна О. - К.: Вид-во «Інститут суспільної трансформації», 2008. $-56 \mathrm{c}$.

18. Зеленько Г. «Навздогінна модернізація»: досвід Польщі та України: монографія / Г. Зеленько. - К.: Критика, 2003. - 215 с.

19. Каплан С. Історія Північноатлантичного Альянсу / С. Каплан // НАТО ревю. Пам’ятне видання до 50-ї річниці НАТО (1949 - 1999) - 1999. - С. 45.

20. Мельникова І.Розвиток відносин України з країнами Центральної та Південно-Східної Європи (90ті роки XX ст.) / І. Мельникова, А. Мартинов //Україна і Свропа $(1990$ - 2000). - К., 2001. - Ч. 1: Україна в міжнародних відносинах з країнами Центральної та Південно-Східної Свропи. Анотована історична хроніка. -308 c.

21. Мороз Д. Досвід вишеградського співробітництва в контексті реалізації сучасної євроінтеграційної стратегії України [Текст] / Д. Мороз // Міжнародні зв'язки України: наукові пошуки і знахідки. - 2005. Вип. 14. - С. 155-161.

22. Мороз Д. Заснування міжнародного регіонального об'єднання Вишеград: передумови і наслідки/ Д. Мороз // Вісник Державної академії керівних кадрів культури і мистецтв. - К., 2005. - № 4. - С.95-100.

23. Мотрук С. Головні напрямки зовнішньої політики Чеської Республіки на рубежі XX - XXI ст. / С. Мотрук // Міжнародні зв'язки України: наукові пошуки і знахідки / Відп. ред. С. В. Віднянський. - К.: Ін-т історії України НАНУ, 2004. - Вип.13: Міжвідомчий збірник наукових праць.- С. 199-207.

24. Постоловський Р. Проблема чехословацької демократії та ï традицій в чеській, словацькій та зарубіжній історіографії / Р. Постоловський // Слов'янський вісник: Міжвідомчий науковий збірник. - Рівне: РПУ,1998. - Вип. 1. - С. 22-37.

25. Солана Х. Бачення майбутнього / Х. Солана // НАТО ревю. Пам'ятне видання присвячене 50-й річниці НАТО. - 1999. - С. 1.

26. Стативка А. Чехія - Словаччина: нова якість двосторонніх відносин / А. Стативка // Політика і час. - 2006. - № 3. - С. 3-8. 
27. Ткачук М.Д. Місце єврорегіонів в інтеграційному полі Європи: досвід країн Вишеградської групи / М.Д.Ткачук // Єврорегіони: потенціал міжетнічної гармонізації. Збірка наукових праць. - Чернівці, 2004. $256 \mathrm{c}$.

28. Україна і Європа (1990 - 2000 рр.). Частина 1. Україна в міжнародних відносинах з країнами Центральної та Південно-Східної Європи. Анотована історична хроніка // Мельникова I. М., Євсеєнко І. В., Знаменська М. В. - К., 2001. - 615 с.

29. Deklarace o spolupraci Ceske a Slovenske federativni republiky, Polske republiky a Madarske republiky na ceste evropske integrace // [Електроний ресурс]. - Режим доступу до статті: www. visegradgroop.org.

30. Ukielski P. The breakdown of the Visegrad cooperation in years $1993-1998$ / P. Ukielski // Slovenskočeské vzt'ahy v kontexte strednej Europy. - Br.: VEDA, - 2005. - S. 250-262.

31. Vachudová A. Česká republika a členstvo v Europskej únii / A. Vachudová // Listi SFPA. - 1999. Februar. - S. 9.

32. Vaduchova A. Visegrádska štvorka: je iná alternatíva? / A. Vaduchova // Medzinárodné otázky. - 1996. № 1. - S. 64-78.

33. Visegrad Scholarships - Approved Projects 2003 - 2012 [Electronic resource] // Visegrad Fund: [site]. Text data. - Bratislava, 2000 - 2015. - Mode of access: http://old.visegradfund.org/scholarships/approved scholarships/- Title from the screen.

1. Andreiko V. I. Dosvid chesko-slovatskoho spivrobitnytstva v konteksti intehratsiinoi stratehii Ukrainy / V. I. Andreiko // Studia Slovakistica. Ukrainsko-Slovatski dialohy. Literaturoznavstvo: Istoriia. - Uzhhorod: UzhNU, 2005. - S. 158-167.

2. Andreiko V. Systema zovnishnoekonomichnoho spivrobitnytstva ChR i SR v period 1990-kh - pochatku 2000-kh rokiv / V. Andreiko // Naukovyi visnyk Uzhhorodskoho universytetu. Seriia: Istoriia. - Uzhhorod: Vydavnytstvo UzhNU «Hoverla», 2006. - Vypusk 16. - S. 99-106.

3. Andreiko V. Systemnyi pidkhid do vyvchennia evoliutsii novitnikh mizhderzhavnykh stosunkiv Chekhii i Slovachchyny / V. Andreiko // Naukovyi visnyk Uzhhorodskoho universytetu. Seriia: Istoriia. - Uzhhorod: Visnyk Karpat, 2005. - Vypusk 14. - S. 101-109.

4. Bokalo N. Problemy i perspektyvy demokratyzatsii v krainakh Tsentralno-Skhidnoi Yevropy (na prykladi Vyshehradskoi chetvirky) / N. Bokalo, S. Trokhymchuk. - Lviv, 2000. - 68 s.

5. Vidnianskyi S. Vzaiemodiia u chasnykiv Vyshehradskoi hrupy iz zovnishnopolitychnym seredovyshchem z etnopolitychnykh pytan / S. Vidnianskyi // Mizhnarodni zviazky Ukrainy: naukovi poshuky i znakhidky. - 2013. Vyp. 22. - S. 253-264.

6. Vidnianskyi S. Zovnishnia polityka Ukrainy: evoliutsiia kontseptualnykh zasad ta problemy realizatsii / S. Vidnianskyi // Ukrainskyi istorychnyi zhurnal. - 2011. - № 4. - S. 55-76.

7. Vidnianskyi S. Ukrainsko-slovatski vidnosyny: zdobutky i perspektyvy / S. Vidnianskyi // Naukovyi visnyk Dyplomatychnoi akademii Ukrainy. - 2002. - Vyp. 7. - S. 221-229.

8. Vovkanych I. Postsotsialistychna transformatsiia v Cheskii Respublitsi: spetsyfika i etapy / I. Vovkanych // Carpatica - Karpatyka. - Uzhhorod: UzhNU, 2003. - Vyp. 21. Politolohichni studii: istoriia, teoriia i praktyka. S. $198-210$.

9. Vovkanych I. Stanovlennia mizhderzhavnykh vzaiemyn Chekhii, Slovachchyny ta Ukrainy / I. Vovkanych // Mizhnarodni zviazky Ukrainy: naukovi poshuky i znakhidky. - 1998. - Vyp. 7. - S. 225-229.

10. Vovkanych I. Metodolohiia porivnialnoho analizu perekhidnykh periodiv istorii krain Tsentralno-Skhidnoi Yevropy druhoi polovyny KhKh st. / I. Vovkanych // Carpatica Karpatyka. - Uzhhorod: Dva kolory, 2001. - Vyp. 10. Aktualni problemy politychnoho ta kulturnoho rozvytku Karpatskoho rehionu v XIX - XX stolittiakh. - S. 161169.

11. Vushehradskaia Evropa: otkuda y kuda? Dva desiatyletyia po puty reform v Venhryy, Polshe, Slovakyy, Chekhyy / pod red. Shyshelynoi L. N. - Moskva: Ves myr, 2010. - 568 s.

12. Herasymchuk T. Krainy Tsentralnoi Yevropy v politytsi Yevropeiskoho Soiuzu (1989 - 2004 rr.) / T. Herasymchuk. - K., 2005. - S. 14-21.

13. Hoilo I. Intehratsiini protsesy v Tsentralnii Yevropi: problemy i trudnoshchi. Yevropa: idei ta protsesy / I. Hoilo // Materialy naukovoho sympoziumu. - Chernivtsi, 1998. - 192 s.

14. Dosvid krain Vyshehradskoi chetvirky na shliakhu do YeS: Mozhlyvosti dlia Ukrainy: Analitychni otsinky. - Uzhhorod, 2003. - 136 s.

15. Duleba A. Slovatsko-ukrainski vidnosyny pislia 1991 roku / A. Duleba // Dosvid krain Vyshehradskoi chetvirky na shliakhu do YeS: mozhlyvosti dlia Ukrainy: analitychni otsinky / Nats. in-t strateh. doslidzh. (Zakarpat. fil.), Fond im. F. Eberta; za red. kol.: V. I. Andriiko, O. S. Vlasiuk, S. I. Mitriaieva (holov. red.). - Uzhhorod: Vydavnytstvo V. Padiaka, 2003. - S. 34-47. 
16. Ievrointehratsiia: dosvid krain Vyshehradskoi chetvirky ta ukrainski realii / Instytut ekonomichnykh doslidzhen ta politychnykh konsultatsii, Uhorskyi instytut mizhnarodnykh sprav (Uhorshchyna), Instytut tsentralnoievropeiskoi polityky SERI (Slovachchyna), Instytut ekonomichnoi polityky EUROPEUM (Chekhiia); za red. Kosse I. - K.: Instytut ekonomichnykh doslidzhen ta politychnykh konsultatsii, 2014. - 88 s.

17. IeS ta mistseve samovriaduvannia: dosvid vyshehradskykh mist ta ukrainska perspektyva: Naukovometodychnyi posibnyk / Za zahalnoiu red. Soskina O. - K.: Vyd-vo «Instytut suspilnoi transformatsii», 2008. - $56 \mathrm{~s}$.

18. Zelenko H. «Navzdohinna modernizatsiia»: dosvid Polshchi ta Ukrainy: monohrafiia / H. Zelenko. - K.: Krytyka, 2003. - 215 s.

19. Kaplan S. Istoriia Pivnichnoatlantychnoho Aliansu / S. Kaplan // NATO reviu. Pamiatne vydannia do 50-yi richnytsi NATO (1949 - 1999) - 1999. - S. 45.

20. Melnykova I. Rozvytok vidnosyn Ukrainy z krainamy Tsentralnoi ta Pivdenno-Skhidnoi Yevropy (90ti roky KhKh st.) / I. Melnykova, A. Martynov // Ukraina i Yevropa (1990 - 2000). - K., 2001. - Ch. 1: Ukraina v mizhnarodnykh vidnosynakh z krainamy Tsentralnoi ta Pivdenno-Skhidnoi Yevropy. Anotovana istorychna khronika. $-308 \mathrm{~s}$.

21. Moroz D. Dosvid vyshehradskoho spivrobitnytstva v konteksti realizatsii suchasnoi yevrointehratsiinoi stratehii Ukrainy [Tekst] / D. Moroz // Mizhnarodni zviazky Ukrainy: naukovi poshuky i znakhidky. - 2005. Vyp. 14. - S. 155-161.

22. Moroz D. Zasnuvannia mizhnarodnoho rehionalnoho obiednannia Vyshehrad: peredumovy i naslidky / D. Moroz // Visnyk Derzhavnoi akademii kerivnykh kadriv kultury i mystetstv. - K., 2005. - № 4. - S. 95-100.

23. Motruk S. Holovni napriamky zovnishnoi polityky Cheskoi Respubliky na rubezhi XX - XXI st. / S. Motruk // Mizhnarodni zv`iazky Ukrainy: naukovi poshuky i znakhidky / Vidp. red. S. V. Vidnianskyi. - K.: In-t istorii Ukrainy NANU, 2004. - Vyp. 13: Mizhvidomchyi zbirnyk naukovykh prats. - C. 199-207.

24. Postolovskyi R. Problema chekhoslovatskoi demokratii ta yii tradytsii $\mathrm{v}$ cheskii, slovatskii ta zarubizhnii istoriohrafii / R. Postolovskyi // Slovianskyi visnyk: Mizhvidomchyi naukovyi zbirnyk. - Rivne: RPU,1998. Vyp. 1. - S. 22-37.

25. Solana Kh. Bachennia maibutnoho / Kh. Solana // NATO reviu. Pamiatne vydannia prysviachene 50-y richnytsi NATO. -1999 . - S. 1.

26. Statyvka A. Chekhiia - Slovachchyna: nova yakist dvostoronnikh vidnosyn / A. Statyvka // Polityka i chas. -2006 . - № 3. - S. 3-8.

27. Tkachuk M. D. Mistse yevrorehioniv v intehratsiinomu poli Yevropy: dosvid krain Vyshehradskoi hrupy / M. D. Tkachuk // Yevrorehiony: potentsial mizhetnichnoi harmonizatsii. Zbirka naukovykh prats. - Chernivtsi, 2004. $-256 \mathrm{~s}$.

28. Ukraina i Yevropa (1990 - 2000 rr.). Chastyna 1. Ukraina v mizhnarodnykh vidnosynakh z krainamy Tsentralnoi ta Pivdenno-Skhidnoi Yevropy. Anotovana istorychna khronika // Melnykova I. M., Yevseienko I. V., Znamenska M. V. - K., 2001. - $615 \mathrm{~s}$.

29. Deklarace o spolupraci Ceske a Slovenske federativni republiky, Polske republiky a Madarske republiky na ceste evropske integrace // [Elektronyi resurs]. - Rezhym dostupu do statti: www. visegradgroop.org.

30. Ukielski P. The breakdown of the Visegrad cooperation in years $1993-1998$ / P. Ukielski // Slovenskočeské vzt'ahy v kontexte strednej Europy. - Br.: VEDA, - 2005. - S. 250-262.

31. Vachudová A. Česká republika a členstvo v Europskej únii / A. Vachudová // Listi SFPA. - 1999. Februar. - S. 9.

32. Vaduchova A. Visegrádska štvorka: je iná alternatíva? / A. Vaduchova // Medzinárodné otázky. - 1996. №1. - S. 64-78.

33. Visegrad Scholarships - Approved Projects 2003 - 2012 [Electronic resource] // Visegrad Fund: [site]. Text data. - Bratislava, 2000 - 2015. - Mode of access: http://old.visegradfund.org/scholarships/approved scholarships/ - Title from the screen.

Стаття надійшла до редакиіії 20.11.2017 p. 